\title{
10
}

\section{Indigenous-owned art centres, tourism and economic benefits: The case of Maruku Arts}

\author{
Marianne Riphagen
}

\section{Art centres and public patronage}

Jon Altman has written extensively about the Indigenous visual arts industry, including the roles played by community-owned Indigenous art centres and the importance of government support for artists and enterprises operating at considerable distance from key markets (Altman 2005, 2007a). He has repeatedly pointed to the economic, social and cultural benefits of government investment in art centres which accrue not just to Indigenous artists and to those who market their work but also to individuals and institutions in sectors like hospitality and tourism (Altman 2007b). Observing that Indigenous art centres constitute hybrid institutions which combine myriad commercial, cultural and social functions, Altman has consistently cautioned against pressuring such centres to operate independent of government funding. However, policymakers have often been reluctant to recognise art centres' mixed functions. As argued by Altman (2005), the ongoing failure to appreciate such hybridity lies at the core of Indigenous art centres' vulnerability and fragility. 
Whilst concerned about policy pressures on Indigenous art centres to reduce their dependency on government subsidy, Altman (2000) has explored opportunities for commercialisation of the industry. Conscious of the popularity of certain forms of Indigenous cultural production amongst tourists, he has suggested that opportunities exist for Indigenous artists and art enterprises to expand into the market for tourist art (Altman 2007b). Altman has also observed that a number of art centres already engage with tourism as they attempt to attract inbound tourists to realise local sales and thus higher returns to their art practitioners. In this paper, I extend Altman's analysis of art centres by examining what happens when an Indigenous art centre does not just venture into the tourist art market but develops a commercial tourism arm. Such a move accords perfectly with the current Indigenous policy climate of mainstreaming (Altman 2010). Nonetheless, as I will demonstrate, it has yielded mixed cultural and economic results. These results illustrate concealed effects of mainstreaming and substantiate Altman's recurrent warnings against the forced commercialisation of Indigenous art centres.

\section{Maruku Arts and tourism development}

Maruku Arts is an Anangu-owned art centre located in Uluru-Kata Tjuta National Park. Established in 1984, Maruku represents a regional arts enterprise that services hundreds of artists across the Anangu Pitjantjatjara Yankunytjatjara (APY) and Ngaanyatjarra (NG) Lands. Its mandate is to buy wooden artefacts, known as punu, from artists based in remote Western Desert communities. These artefacts are subsequently sold wholesale or through Maruku's gallery inside the National Park. During the mid-1980s, Altman researched the economic impact of tourism on the Mutitjulu community, home to Maruku's warehouse and administration. He demonstrated that Maruku provided local and regional artists with important discretionary non-government income and the chance to profit economically from tourism without being forced to engage directly with tourists. Between April 1985 and May 1986 approximately 81 per cent of Maruku's payments to producers went to regionally based Anangu. During this 58 -week period, $\$ 26,522$ was paid to local artists from the Mutitjulu Community who could be identified in purchase books (Altman 1991a: 83; 1991b: 114). Altman suggested that with the 
expected growth in the tourism industry and expansion of the art centre, economic benefits for regional producers would only increase. In addition, he concluded that as long as no radical changes occurred in the regional economies of the APY and NG Lands, the supply of punu available for sale should be plentiful.

Thirty years later, as I commenced fieldwork in Mutitjulu, Maruku's future no longer looked as bright as it did when Altman conducted his study. Like other Indigenous art centres, Maruku had been negatively affected by the downturn of the Aboriginal art market following the onset of the global financial crisis (GFC) (Wilson-Anastasios 2013). As private art galleries in the cities strained to make ends meet, several of the selling exhibitions planned by Maruku were cancelled (Scollay C, pers. comm., 24 March 2014). More importantly, this art centre suffered from the decline in visitors to Uluru-Maruku's principal market. The strong Australian dollar saw many domestic travellers forgo a trip to the Red Centre and journey overseas instead. International tourists who experienced reduced income security due to the GFC decided not to travel to Australia (Tourism Australia 2011). According to the Director of National Parks (2010: 54; 2011: 51; 2012: 51), the number of entry tickets sold to visitors to Uluru-Kata Tjuta National Park aged 16 years and above declined from 334,240 in 2009-10 and 269,242 in 2010-11 to 264,144 in 2011-12.

It is important to note that Maruku's applications for funding from the Australian Government's Indigenous Visual Arts Industry Support (IVAIS) program had been rejected for several years. As suggested by General Manager Clive Scollay (pers. comm., 15 September 2014), Maruku's inability to obtain support from IVAIS had been the result of an impression harboured by public servants that the art centre, regardless of the difficulties faced, is performing comparatively well. It is not entirely surprising that such an impression exists, since Maruku has long been promoted as an Indigenous entrepreneurial success story (e.g. Wright 2000: 115). Yet, while the art centre's performance has changed, its access to arts funding has not. ${ }^{1}$ Recurrent operating losses combined with the absence of structural

$1 \quad$ Maruku Arts recently applied for funding under the Australian Government's Indigenous Advancement Strategy (IAS), which began on 1 July 2014. The art centre's proposal was not funded. 
government support forced Maruku to identify new revenue options. ${ }^{2}$ In 2012, its executive committee and management decided to diversify and develop arts-based tourism activities, most notably dot painting workshops. Several months earlier, in October 2011, Maruku had already established an art market in Yulara, the town outside of the National Park where tourists usually eat, sleep and shop. Unlike other art centres that dabble in tourism, Maruku Arts has since become an accredited tourism business. It has even enrolled in the Indigenous Champions Program run by Tourism Australia and Indigenous Business Australia.

\section{Consequences of commercialisation}

The decision to create a new sales outlet and arts-based activities for visitors to Uluru was aimed at improving Maruku's solvency for the benefit of the art centre's Anangu directors and artists. Nonetheless, the establishment of the art market and dot painting workshops has had unforeseen cultural and economic effects. Here, I will outline these effects by differentiating between Anangu producers in the Mutitjulu Community adjacent to Uluru and Anangu artists who reside regionally, at a distance from Maruku Arts.

\section{Mutitjulu and the increase in income}

For Mutitjulu-based artists, the art centre's new direction has resulted in an important income increase. To run the art market in Yulara, Maruku casually employs two local producers. Initially, the market operated on working days only. However, since the beginning of 2013 tourists have been able to shop at the market on a daily basis. Each day, Anangu from Mutitjulu are driven to and from Yulara where they demonstrate the art of painting to visitors. ${ }^{3}$ Besides receiving a demonstration fee of $\$ 80$ a day, these artists also earn money by

2 The audited financial statements for the 2009-10, 2010-11, 2011-12 and 2012-13 financial years respectively recorded an operating loss of $\$ 340,573$, an operating loss of $\$ 231,289$, an operating surplus of $\$ 85,185$ and an operating loss of $\$ 96,841$ (ORIC 2014).

3 Because Mutitjulu is located inside the National Park, its residents are not allowed to fell trees to make woodcraft. Therefore, Maruku has always made an exception from its focus on woodcraft by buying paintings from local producers. 
selling paintings made at the market to tourists. ${ }^{4}$ Until April 2013, Maruku fully paid artists for each painting produced at the market on the day. Since then, a consignment system has been introduced for all artworks except small items such as bookmarks and canvases sized 15 by 20 centimetres. Once paintings are sold, producers receive 40 per cent of the sale price.

I have analysed production and sales data for Maruku's art market from its launch in October 2011 until April 2014, focusing on four sample months each year. The sample months have been chosen to reflect the seasonal nature of tourism at Uluru, with February representing the low season, July representing the high season and April and October corresponding to the shoulder seasons. As demonstrated by Table 10.1, Maruku typically puts over $\$ 10,000$ a month of market money into the Mutitjulu community. ${ }^{5}$ Because artists attend the market on a casual basis, the income they derive from their work is not sufficient to realise economic autonomy. Yet, certain Mutitjulu residents are able to carve out a substantial salary. In July 2013, the three highest earning artists respectively received $\$ 1,968$ for nine days' work; $\$ 1,260$ for five days' work; and \$1,021 for four days' work. In October 2013, the three highest earning artists respectively received $\$ 2,012$ for seven days' work; $\$ 1,371$ for five days' work; and $\$ 881$ for four days' work. This amounts to well over $\$ 200$ for an approximately six-hour work day, excluding travel.

4 Until the beginning of 2015 artists received a demonstration fee of \$100 each day. Maruku reduced this payment to $\$ 80$ because the art market at Yulara was operating at a loss.

5 My analysis of art market data after the introduction of Maruku's consignment system is based on market sheets. These sheets do not list payments to artists in cash for non-consignment items like bookmarks and small paintings. As a result, the income earned by Mutitjulu-based artists for April 2013, July 2013, October 2013, February 2014 and April 2014 is slightly higher in reality than reported here. The majority of producers earned an estimated $\$ 40$ on top of their recorded income from the creation of non-consignment articles each day they worked at the market. 
ENGAGING INDIGENOUS ECONOMY

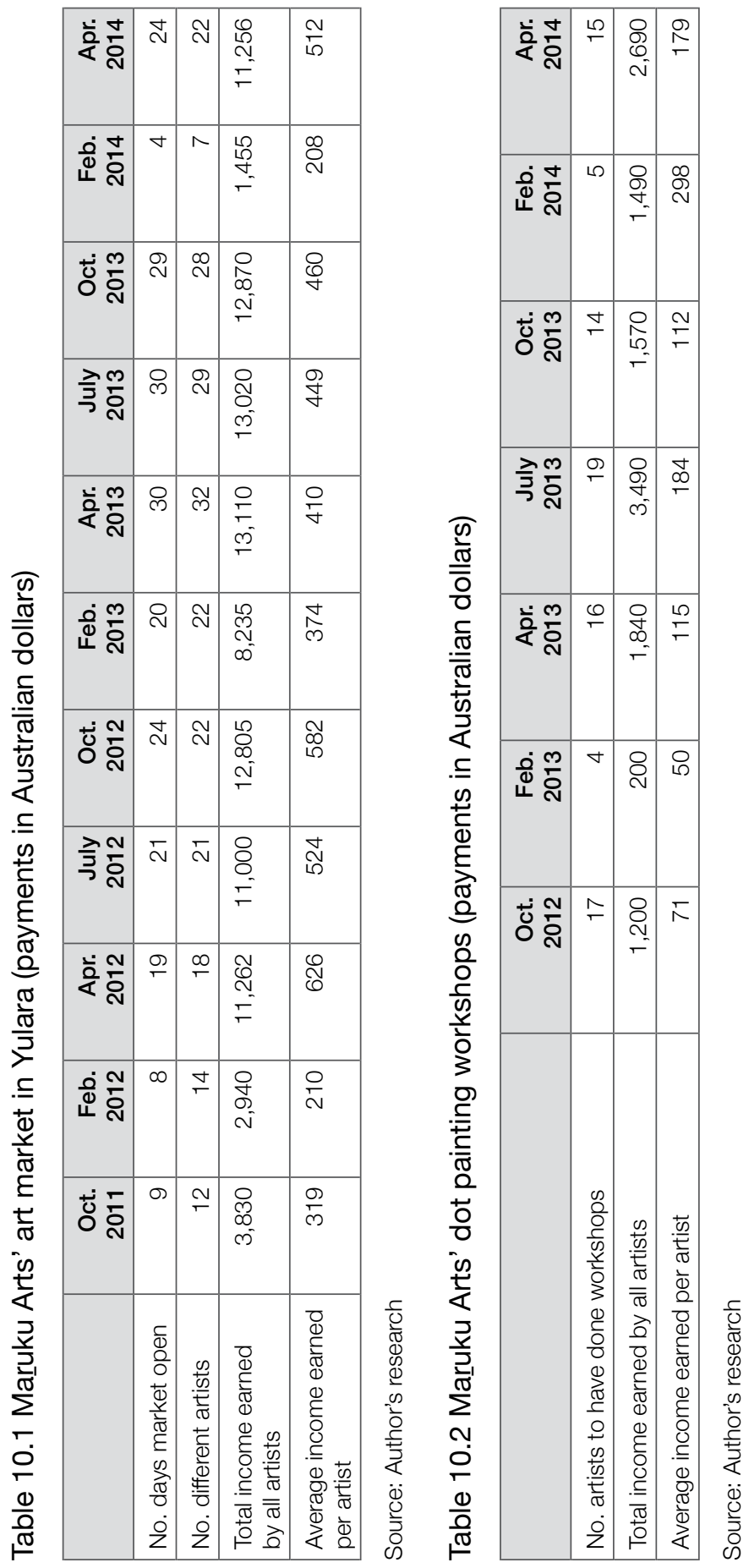


The 90-minute dot painting workshops, which also rely on local labour, are held twice daily provided that sufficient tourists have signed up. Until August 2014 the morning workshop would be staged in Yulara whilst the afternoon workshop took place inside Uluru-Kata Tjuta National Park. In the morning, one Anangu artist already at work for Maruku at the market would be asked to conduct the workshop alongside a non-Indigenous host. This artist would then receive $\$ 50$ on top of his or her market earnings for the day as compensation. Afternoon workshops operated independent from the art market due to their occurrence inside the National Park, away from Yulara. To conduct these workshops, a Maruku employee would normally pick up a new artist from Mutitjulu and pay this producer $\$ 120$ for demonstrating acrylic painting and the symbolism associated with Western Desert art to tourists. Table 10.2 demonstrates the income earned by Anangu from Mutitjulu from the dot painting workshops. As before, I focus on the four sample months which represent different tourism seasons at Uluru. While the total income earned by all artists through the workshops varies considerably and is by no means high, an estimated 78 per cent of all casual payments accrued to producers already at work at the art market. The money thus earned by artists from the dot painting workshops principally constitutes a top up on their existing Maruku income.

It is important to note that payments to Mutitjulu-based producers for their involvement in Maruku's new tourism activities represent an addition to the income already earned by local Anangu from selling their art, especially acrylic paintings, directly to Maruku's warehouse.

\section{The regional economy}

While Anangu residents of Mutitjulu have benefited from the introduction of Maruku's tourism activities, their regionally based relatives have been less fortunate. Due to their residence in remote communities at a distance from the National Park, Anangu who comprise Maruku's regional constituency have not been in the position to regularly work at the art market or present the dot painting workshops. During research trips to Mutitjulu in July and September 2014, I encountered an almost empty warehouse. The shelves normally stocked with wooden artefacts, predominantly purchased from regional Anangu communities, were largely unfilled. The lack of punu can be 
explained through an analysis of Maruku's community buying data. During the financial year 2013-14, Maruku spent almost $\$ 64,000$ on punu in remote communities on the APY and NG Lands. ${ }^{6}$ This is down considerably from the more than $\$ 175,000$ spent on woodcraft during the previous financial year. Indeed, the amount spent by Maruku on buying punu from regional producers during the 2013-14 financial year was the lowest on record for the period between July 2006 and June 2014 (see Table 10.3). ${ }^{7}$ Between July 2013 and June 2014, 12 out of 17 regional communities serviced by the art centre saw a drop in income earned by punu makers compared with the previous year.

Table 10.3 Maruku Arts' total annual expenditure on punu in 17 regional Anangu communities (expenditure in Australian dollars per financial year)

\begin{tabular}{|l|r|}
\hline Year & Expenditure \\
\hline $2006-07$ & 107,880 \\
\hline $2007-08$ & 305,118 \\
\hline $2008-09$ & 152,697 \\
\hline $2009-10$ & 113,256 \\
\hline $2010-11$ & 68,445 \\
\hline $2011-12$ & 150,378 \\
\hline $2012-13$ & 175,535 \\
\hline $2013-14$ & 63,953 \\
\hline
\end{tabular}

Source: Author's research

In the 2011-12 financial year, Maruku received funding from the Aboriginals Benefit Account to upgrade infrastructure and encourage Anangu punu making regionally. This funding enabled the so-called punu man - the employee responsible for purchasing woodcraft on a regular basis - to spend more time with artists in communities serviced by Maruku, to provide art practitioners with the transport and tools needed to source wood for punu making and to focus on skills development. The staff member assigned to this role at the beginning

6 The regional communities serviced by Maruku and analysed here include Amata, Blackstone, Docker River, Ernabella, Finke, Fregon, Indulkana, Jameson, Kalka, Mimili, Nyapari, Pipalyatjara, Tjukurla, Wanarn, Warakurna, Warburton and Wingellina.

7 Maruku's total expenditure on punu during the 2010-11 financial year was also low. An overstocked warehouse combined with declining sales to tourists compelled the art centre to temporarily reduce its community buying trips (Scollay C, pers. comm., 17 March 2014). 
of 2012 dedicated himself to these development tasks. However, in December 2013, this punu man left Maruku Arts disillusioned. As he explained to me, the new tourism activities had impacted his ability to spend time and money on facilitating punu making (Ellemunter E, pers. comm., 17 November 2013). In an attempt to get its commercial tourism business off the ground, Maruku had to reallocate scarce resources - money and labour - to the dot painting workshops and market stall. In 2013, the punu man found that on the rare trips he was able to undertake, Anangu no longer had a good supply of punu available. Indeed, people told him they thought the punu man would no longer be coming. Eventually, this punu man left as his efforts to stimulate punu production appeared unsuccessful.

The data for the 2012-13 and 2013-14 financial years tell a story of an almost $\$ 112,000$ loss of income for regional Anangu communities, a decline in the production of an art form that has made Maruku stand out amongst Australia's Indigenous art centres and an apparent challenge to cultural maintenance. However, there is also a bigger narrative. Clive Scollay (pers. comm., 18 June 2013) argues that the decrease in Anangu woodcraft production and the diminishing expenditure on punu by the art centre are structural issues which can principally be attributed to the competition presented by painting. Scollay contends that since the establishment and flourishing of several art centres on the APY and NG Lands, Anangu who previously made punu have now turned their attention to painting. Painting usually costs less time and effort and the income derived from making such artworks tends to be higher than that realised through making woodcraft. The general manager thus explains Maruku's reduced expenditure on punu by highlighting problems with the supply side.

Fig. 10.1 demonstrates that between July 2006 and June 2014 Maruku's spending on punu in regional Anangu communities indeed represented a downward trend $\left[F(1,134)=4.3, \quad P<0.05, \quad r^{2}=0.03\right]$. Additional regression analysis conducted for communities individually revealed a downward trend of Maruku's expenditure on punu for 12 out of 17 communities. For Amata, Fregon and Indulkana, this downward trend was significant $\left[P<0.05, r^{2}=0.6\right.$ for all three communities]. 


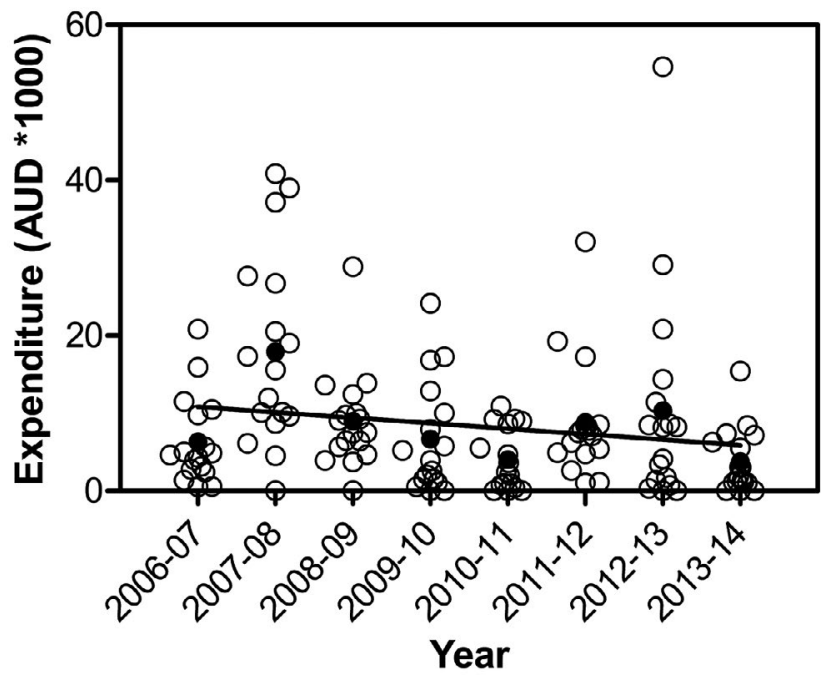

Fig. 10.1 Maruku Arts' expenditure on punu in 17 regional Anangu communities per financial year (data per community (open circles), yearly average (closed circles) and linear regression line shown)

Source: Author's research

Interestingly, 75 per cent of communities that manifested a trend toward declining punu expenditure were home to a communityowned Indigenous art centre. Among those communities that did not evince a downward trend, only 40 per cent had an art centre. Fig. 10.2 and Fig. 10.3 respectively show Maruku's annual expenditure on punu in 11 Anangu communities with an art centre and six communities without. ${ }^{8}$ Whilst the downward trend observed in communities with an art centre is statistically significant $\left[F(1,86)=10.2, P<0.01, r^{2}=0.11\right]$, no statistical significance has been established for communities without an art centre $\left[F(1,46)=0.1, P=0.8, r^{2}=0.002\right]$.

8 Amata, Blackstone, Ernabella, Fregon, Indulkana, Kalka, Mimili, Nyapari, Pipalyatjara, Tjukurla and Warakurna all had independent, fully functional art centres for the entire period surveyed. 


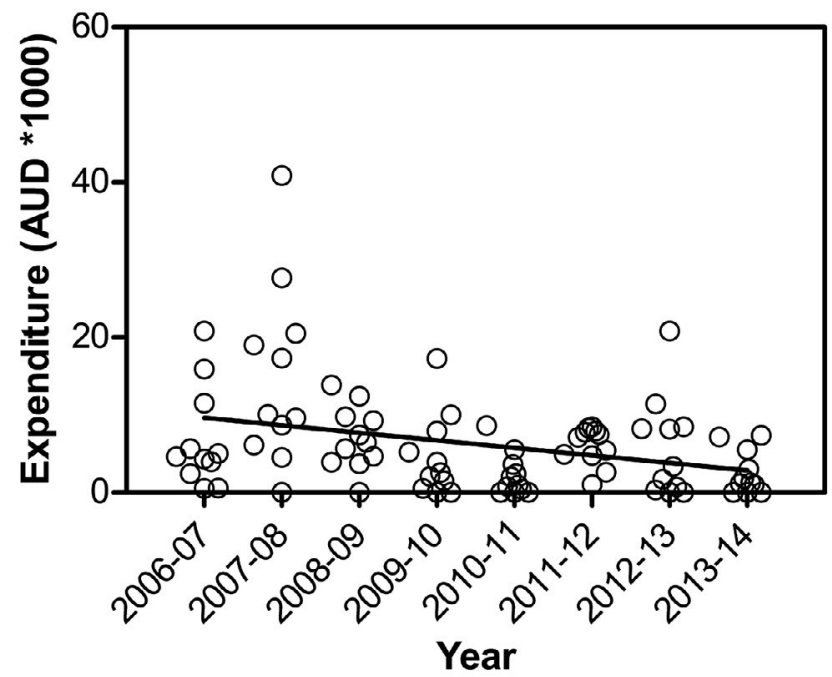

Fig. 10.2 Maruku Arts' expenditure on punu in 11 regional Anangu communities with an art centre per financial year (data per community (open circles) and linear regression line shown) Source: Author's research

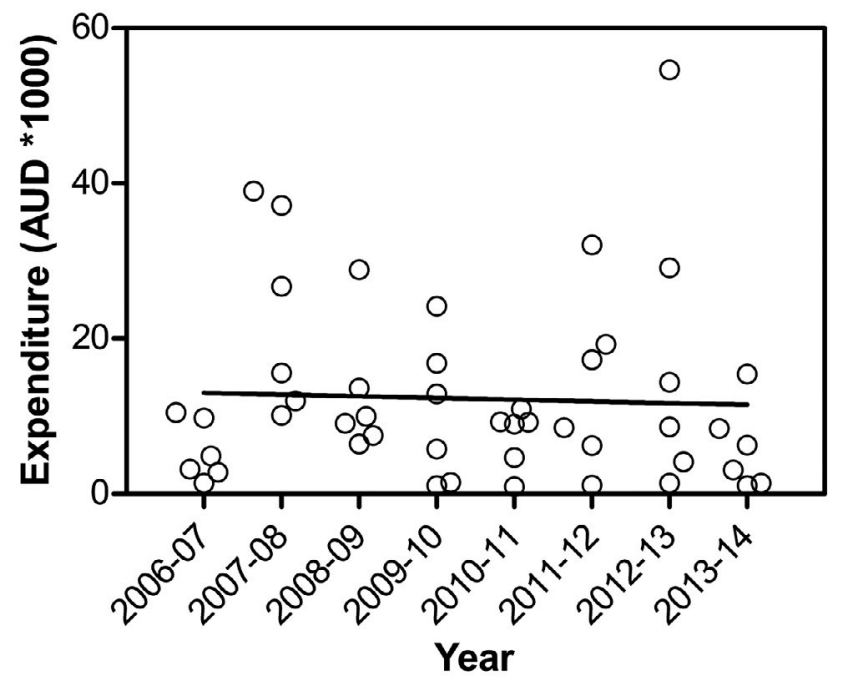

Fig. 10.3 Maruku Arts' expenditure on punu in six regional Anangu communities without an art centre per financial year (data per community (open circles) and linear regression line shown)

Source: Author's research 
These preliminary findings provide support for Scollay's argument that the decrease in income realised by Anangu through punu production precedes Maruku's development of tourism activities and relates to the prospering of painting. They do not, however, detract from the impact of the new activities on Maruku's capacity to invest in the practice of punu making.

\section{Concluding remarks}

The case study of Maruku Arts illustrates what can happen when an Indigenous art centre is forced to commercialise. Whilst the art centre has readily received support from Indigenous Business Australia, Tourism Australia and Tourism NT to establish itself within the tourism arena, it continues to lack the resources to properly facilitate punu making regionally. Today, the balance between Maruku's payments to local and regional producers differs substantially from the strong emphasis on regional expenditure encountered by Jon Altman during his research in Mutitjulu three decades ago. Those who have primarily benefited from Maruku's new direction have been locally based Anangu artists who already enjoyed access to more economic opportunities than their relatives living regionally.

Yet, it is not just about economics, as Altman has emphasised in his writings about Indigenous art. The decline in income earned by punu makers regionally has further impacted on a cultural tradition already in jeopardy because of structural changes to the regional economy since Altman's study during the mid-1980s. The production of high quality wooden artefacts is currently at risk. Maruku's recent investments in tourism products principally based on the art of dot painting have drawn attention and resources away from Anangu woodcraft. While policymakers may applaud the art centre's new profit-oriented direction, the advanced commercialisation and mainstreaming seen in the case of Maruku Arts evidently poses inadvertent risks to Indigenous economic and cultural sustainability. 


\section{Acknowledgements}

The author would like to thank directors, staff and artists of Maruku Arts for permitting and supporting this research; Howard Morphy and David Throsby for initiating and leading this research project, Jon Altman for his advice and assistance; Katya Petetskaya for her useful comments on this paper; and H. Christiaan Stronks for his help with the regression analysis. This work was supported by the Australian Research Council under Grant DP120101387.

\section{References}

Altman JC (1988). The economic basis for cultural reproduction. In West W (ed.), The inspired dream: life as art in Aboriginal Australia, Queensland Art Gallery, Brisbane.

Altman JC (1991a). The economic impact of tourism on the Mutitjulu community. In Central Land Council, Pitjantjatjara Council \& Mutitjulu Community, Sharing the park: Anangu initiatives in Ayers Rock tourism, Institute for Aboriginal Development, Alice Springs.

Altman JC (1991b). The economic impact of tourism at Uluru National Park on other Aboriginal communities in Central Australia. In Central Land Council, Pitjantjatjara Council \& Mutitjulu Community, Sharing the park: Anangu initiatives in Ayers Rock tourism, Institute for Aboriginal Development, Alice Springs.

Altman JC (2000). The Indigenous visual arts industry: issues and prospects for the next decade. Artlink 20(1):86-92.

Altman JC (2005). Brokering Aboriginal art: a critical perspective on marketing, institutions, and the state, Centre for Leisure Management Research, Deakin University, Melbourne.

Altman JC (2007a). Art business: the Indigenous visual arts infrastructure. In Perkins $\mathrm{H}$ \& West $\mathrm{M}$ (eds), One sun, one moon: Indigenous art in Australia, Art Gallery of NSW, Sydney. 
Altman JC (2007b). Inquiry into Australia's Indigenous visual arts and craft sector, submission to the Senate Environment, Communications, Information Technology and the Arts Committee, Topical Issue 04/2007, Centre for Aboriginal Economic Policy Research, The Australian National University, Canberra.

Altman JC (2010). What future for remote Indigenous Australia? Economic hybridity and the neoliberal turn. In Altman JC \& Hinkson M (eds), Culture crisis: anthropology and politics in Aboriginal Australia, UNSW Press, Sydney.

Director of National Parks (2010). State of the parks report 2009-10, Parks Australia, Canberra.

Director of National Parks (2011). State of the parks report 2010-11, Parks Australia, Canberra.

Director of National Parks (2012). State of the parks report 2011-12, Parks Australia, Canberra.

ORIC (Office of the Registrar of Indigenous Corporations) (2014). Anangu Uwankaraku Punu Aboriginal Corporation Compliance Notice-s439-20(1), ORIC, Canberra.

Tourism Australia (2011). Exchange rates: challenges and opportunities for Australian tourism, Tourism Australia, Canberra.

Wilson-Anastasios M (2013). Desert artists draw a line in the sand. Sydney Morning Herald 4 May.

Wright F (2000). The art \& craft centre story volume three: good stories from out bush, ATSIC, Canberra. 
This text is taken from Engaging Indigenous Economy: Debating diverse approaches, edited by Will Sanders, published 2016 by ANU Press, The Australian National University, Canberra, Australia. 